\title{
Development and Application of a gp60-Based Subtyping Tool for Cryptosporidium bovis
}

\author{
Weijian Wang ${ }^{1,2}{ }^{\oplus}$, Muchun Wan ${ }^{1}$, Fang Yang ${ }^{1}, \mathrm{Na} \mathrm{Li}^{1}{ }^{1}$, Lihua Xiao ${ }^{1,2} \oplus$, Yaoyu Feng ${ }^{1,2, *} \odot$ and Yaqiong Guo ${ }^{1,2, *}$ \\ 1 Center for Emerging and Zoonotic Diseases, College of Veterinary Medicine, \\ South China Agricultural University, Wushan Road, Guangzhou 510642, China; \\ wjwang@stu.scau.edu.cn (W.W.); Muchun_Wan@outlook.com (M.W.); yf1432277601@163.com (F.Y.); \\ nli@scau.edu.cn (N.L.); lxiao1961@gmail.com (L.X.) \\ 2 Guangdong Laboratory for Lingnan Modern Agriculture, Wushan Road, Guangzhou 510642, China \\ * Correspondence: yyfeng@scau.edu.cn (Y.F.); guoyq@scau.edu.cn (Y.G.)
}

Citation: Wang, W.; Wan, M.; Yang, F.; Li, N.; Xiao, L.; Feng, Y.; Guo, Y. Development and Application of a gp60-Based Subtyping Tool for Cryptosporidium bovis. Microorganisms 2021, 9, 2067. https://doi.org/ $10.3390 /$ microorganisms 9102067

Academic Editor: Gereon R. M. Schares

Received: 8 September 2021

Accepted: 28 September 2021

Published: 30 September 2021

Publisher's Note: MDPI stays neutral with regard to jurisdictional claims in published maps and institutional affiliations.

Copyright: (c) 2021 by the authors. Licensee MDPI, Basel, Switzerland. This article is an open access article distributed under the terms and conditions of the Creative Commons Attribution (CC BY) license (https:// creativecommons.org/licenses/by/ $4.0 /)$.

\begin{abstract}
Cryptosporidium bovis is a common enteric pathogen in bovine animals. The research on transmission characteristics of the pathogen is hampered by the lack of subtyping tools. In this study, we retrieve the nucleotide sequence of the $60 \mathrm{kDa}$ glycoprotein (GP60) from the whole genome sequences of $C$. bovis we obtained previously and analyze its sequence characteristics. Despite a typical structure of the GP60 protein, the GP60 of C. bovis had only 19.3-45.3\% sequence identity to those of other Cryptosporidium species. On the basis of the gene sequence, a subtype typing tool was developed for C. bovis and used in the analysis of 486 C. bovis samples from dairy cattle, yaks, beef cattle, and water buffalos from China. Sixty-eight sequence types were identified from 260 subtyped samples, forming six subtype families, namely XXVIa to XXVIf. The mosaic sequence patterns among subtype families and the 121 potential recombination events identified among the sequences both suggest the occurrence of genetic recombination at the locus. No obvious host adaptation and geographic differences in the distribution of subtype families were observed. Most farms with more extensive sampling had more than one subtype family, and the dominant subtype families on a farm appeared to differ between pre- and post-weaned calves, indicating the likely occurrence of multiple episodes of $C$. bovis infections. There was an association between XXVId infection and occurrence of moderate diarrhea in dairy cattle. The subtyping tool developed and the data generated in the study might improve our knowledge of the genetic diversity and transmission of C. bovis.
\end{abstract}

Keywords: Cryptosporidium bovis; 60-kDa glycoprotein; subtyping tool; genetic diversity; multiple infection episodes

\section{Introduction}

Cryptosporidium spp. are important enteric parasites in humans and a variety of animals [1-3]. Bovine animals are common hosts of the parasites. In pre-weaned calves, cryptosporidiosis is a major cause of outbreaks of diarrhea [4-8]. In post-weaned calves and adult cattle, subclinical cryptosporidiosis can lead to growth retardation and reduced milk production, respectively $[9,10]$.

Cryptosporidium bovis is one of the four common Cryptosporidium species in cattle. Previous studies indicated that $C$. bovis mainly infected post-weaned calves in industrialized nations and generally caused asymptomatic infections [11,12]. However, in recent years, C. bovis has been commonly found in pre-weaned calves in some Asian and European countries and is responsible for moderate diarrhea $[4,5,11,13-15]$. This difference in the occurrence of $C$. bovis could reflect genetic heterogeneity in infectivity and pathogenicity. Nevertheless, due to the lack of a subtyping tool, little is known of the genetic diversity within the bovine-specific species.

Sequence analysis of the $60 \mathrm{kDa}$ glycoprotein gene ( $g$ p60) is commonly used in subtyping Cryptosporidium spp. [16]. This tool has been used in the identification of 
infection sources and transmission dynamics of Cryptosporidium species in humans and animals [17-20]. Among the three common intestinal Cryptosporidium species in cattle, subtyping tools targeting the gp60 gene are available for C. parvum [21] and C. ryanae [22]. Despite the recent sequencing of the genome of $C$. bovis [23], a subtyping tool is yet to be developed for this species.

In this study, we identify the gp60 gene sequence from the whole genome sequences of $C$. bovis we obtained previously and develop a subtyping tool on the basis of it. The subtyping tool is used in the characterization of C. bovis from dairy cattle, beef cattle, yaks, and water buffalos.

\section{Materials and Methods}

\subsection{Ethics Statement}

All fecal samples used in this study were previously collected from cattle with the permission of the farm managers, using procedures in compliance with the Animal Ethics Procedures and Guidelines of the People's Republic of China. The research protocol was reviewed and approved by the Ethics Committee of the South China Agricultural University.

\subsection{Samples}

DNA preparations from 486 fecal samples of cattle were used in this study, including those from dairy cattle $(n=393)$, yaks $(n=73)$, beef cattle $(n=16)$, and water buffaloes $(n=4)$ (Table 1). These fecal samples were previously collected on 33 farms in nine provinces of China [5,24-27] and identified as C. bovis-positive by PCR and sequence analysis of the SSU $r R N A$ gene [28]. The consistency of fecal samples was available from dairy cattle, except those collected from Farm Foshan $(n=20)$. Three categories were assigned to the samples: formed feces with no diarrhea $(n=266)$, loose feces with moderate diarrhea $(n=74)$ and liquid feces with watery diarrhea $(n=33)$. The DNA preparations from the fecal samples were stored at $-80{ }^{\circ} \mathrm{C}$ until being analyzed by the $C$. bovis gp60 PCR.

\subsection{Identification of the gp60 Sequence of C. bovis}

To obtain the nucleotide sequence of the gp60 gene of C. bovis, the whole genome sequences (SRX6096269) of one C. bovis isolate ECUST 42482 from a dairy calf in Shanghai, China were downloaded from GenBank [23]. Using the gp60 sequence (cgd6_1080) of C. parvum as the reference, the gp60 gene of C. bovis was identified among the whole genome sequences by a blastn analysis. The coding region of the C. bovis gp60 gene was predicted using FGENESH (http:/ / www.softberry.com/berry.phtml?topic=fgenesh\& group $=$ programs\&subgroup $=$ gfind, accessed on 9 December 2020) and confirmed by a blastp search of the NCBI database.

\subsection{PCR of the gp60 Gene}

On the basis of the nucleotide sequence of the gp60 gene, primers were designed to amplify a 1300-bp fragment of the gene using nested PCR. The sequences of primers used were 5'-ATGCGACTTACGCTCTACATTACTCT-3' (Bovis-gp60-F1) and 5'-GACAAAATGAAGG CTGAGATAGATGGGA-3' (Bovis-gp60-R1) in primary PCR, and 5'-CCTCTCGG CATTTATTGCCCT-3' (Bovis-gp60-F2) and 5'-ATACCTAAGGCCAAATGCTGATGAA-3' (Bovis-gp60-R2) in secondary PCR. The PCR reaction was $50 \mu \mathrm{L}$ in volume, which contained $1 \mu \mathrm{L}$ DNA (for primary PCR) or $2 \mu \mathrm{L}$ primary PCR product (for secondary PCR), $0.25 \mu \mathrm{M}$ primary primers or $0.5 \mu \mathrm{M}$ secondary primers and $1 \times$ PCR master mix (Thermo Scientific, Waltham, MA, USA). In addition, $400 \mathrm{ng} / \mu \mathrm{L}$ nonacetylated bovine serum albumin (Sigma-Aldrich, St. Louis, MO, USA) was used in primary PCR to reduce PCR inhibitors. The amplification program consisted of a pre-denaturation at $94{ }^{\circ} \mathrm{C}$ for $5 \mathrm{~min}, 35$ cycles of $94{ }^{\circ} \mathrm{C}$ for $45 \mathrm{~s}, 55^{\circ} \mathrm{C}$ for $45 \mathrm{~s}$, and $72{ }^{\circ} \mathrm{C}$ for $90 \mathrm{~s}$, and a final extension at $72{ }^{\circ} \mathrm{C}$ for $10 \mathrm{~min}$. The secondary PCR products were visualized under UV light after $1.5 \%$ agarose gel electrophoresis. 
Table 1. Sources and subtype family identity of Cryptosporidium bovis samples used in the study.

\begin{tabular}{|c|c|c|c|c|c|c|}
\hline Host & Province & Farm & $\begin{array}{c}\text { No. of } \\
\text { Samples } \\
\text { Analyzed }\end{array}$ & $\begin{array}{l}\text { No. of Samples } \\
\text { Positive by gp60 } \\
\text { PCR (\%) }\end{array}$ & $\begin{array}{c}\text { No. of } \\
\text { Samples } \\
\text { Subtyped }\end{array}$ & Subtype Family (No. of Samples) \\
\hline \multirow{22}{*}{$\begin{array}{l}\text { Dairy } \\
\text { cattle }\end{array}$} & Heilongjiang & Harbin & 10 & $10(100.0)$ & 9 & XXVIa (8), XXVIb (1) \\
\hline & \multirow{3}{*}{ Hebei } & Shijiazhuang-1 & 14 & $11(78.6)$ & 10 & XXVIb (3), XXVId (3), XXVIe (2), XXVIc (1), XXVIf (1) \\
\hline & & Shijiazhuang-2 & 6 & $5(83.3)$ & 4 & XXVIb (3), XXVIc (1) \\
\hline & & Yichuan-1 & 14 & $2(14.3)$ & 2 & XXVId (1), XXVIf (1) \\
\hline & \multirow{2}{*}{ Henan ${ }^{1}$} & Xinxiang-1 & 5 & $1(20.0)$ & 1 & XXVId (1) \\
\hline & & Xinxiang-2 & 4 & $1(25.0)$ & 1 & XXVIf (1) \\
\hline & \multirow[t]{2}{*}{ Jiangsu } & Xinghua & 13 & $10(76.9)$ & 10 & XXVIa (6), XXVIe (3), XXVIf (1) \\
\hline & & Shanghai-1 & 61 & $38(62.3)$ & 37 & XXVIc (35), XXVIb (1), XXVIe (1) \\
\hline & \multirow{4}{*}{ Shanghai ${ }^{1}$} & Shanghai-2 & 30 & $17(56.7)$ & 8 & XXVId (5), XXVIc (1), XXVIe (1), XXVIf (1) \\
\hline & & Shanghai-3 & 18 & $8(44.4)$ & 7 & XXVIa (4), XXVIc (2), XXVId (1) \\
\hline & & Shanghai-4 & 16 & $8(50.0)$ & 8 & XXVIb (7), XXVIc (1) \\
\hline & & Shanghai-5 & 12 & $6(50.0)$ & 3 & XXVIc (2), XXVIe (1) \\
\hline & \multirow{4}{*}{ Yunnan } & Dali-1 & 40 & $30(75.0)$ & 23 & XXVIb (9), XXVIa (4), XXVIc (4), XXVIf (4), XXVId (2) \\
\hline & & Dali-2 & 10 & $9(90.0)$ & 9 & XXVIa (9) \\
\hline & & Zhaoqing & 28 & $18(64.3)$ & 17 & XXVIe (12), XXVIc (3), XXVIa (1), XXVIb (1) \\
\hline & & Guangzhou & 25 & $21(84.0)$ & 17 & $\begin{array}{c}\text { XXVIe (10), XXVIf (3), XXVId (2), XXVIa (1), } \\
\text { XXVIc (1) }\end{array}$ \\
\hline & \multirow{5}{*}{ Guangdong } & Yangjiang & 20 & $17(85.0)$ & 17 & XXVIe (8), XXVIb (5), XXVIc (3), XXVId (1) \\
\hline & & Foshan & 20 & $15(75.0)$ & 15 & XXVIb (14), XXVId (1) \\
\hline & & Qingyuan & 18 & $13(72.2)$ & 12 & XXVId (6), XXVIa (3), XXVIe (2), XXVIc (1) \\
\hline & & Conghua & 15 & $12(80.0)$ & 11 & XXVIe (8), XXVIa (2), XXVIb (1) \\
\hline & & Lianzhou & 14 & $10(71.4)$ & 8 & XXVIa (6), XXVIe (2) \\
\hline & \multirow[t]{4}{*}{ subtotal } & & 393 & $262(66.7)$ & 229 & 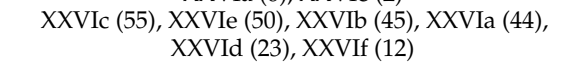 \\
\hline \multirow{10}{*}{ Yak } & & Guoluo & 10 & $6(60.0)$ & 6 & XXVIf (4), XXVIe (2) \\
\hline & & Qilian-1 & 13 & $4(30.8)$ & 4 & XXVIb (2), XXVIc (2) \\
\hline & & Qilian-2 & 12 & $2(16.7)$ & 1 & XXVIe (1) \\
\hline & \multirow{6}{*}{ Qinghai ${ }^{1}$} & Qilian-3 & 9 & $2(22.2)$ & 2 & XXVIa (1), XXVIf (1) \\
\hline & & Menyuan & 10 & $3(30.0)$ & 3 & XXVIa (3) \\
\hline & & Hainan-1 & 6 & $2(33.3)$ & 2 & XXVIa (1), XXVIb (1) \\
\hline & & Hainan-2 & 4 & $1(25.0)$ & 1 & XXVIf (1) \\
\hline & & Hainan-3 & 3 & $3(100.0)$ & 3 & XXVIf (3) \\
\hline & & Yushu & 6 & $4(66.7)$ & 4 & XXVIc (3), XXVIa (1) \\
\hline & subtotal & & 73 & $27(37.0)$ & 26 & XXVIf (9), XXVIa (6), XXVIc (5), XXVIb (3), XXVIe (3) \\
\hline \multirow{3}{*}{$\begin{array}{c}\text { Beef } \\
\text { cattle }\end{array}$} & \multirow{3}{*}{$\begin{array}{l}\text { Henan }^{1} \\
\text { subtotal }\end{array}$} & Yichuan-2 & 11 & $3(27.3)$ & 3 & XXVIc (1), XXVId (1), XXVIe (1) \\
\hline & & Yichuan-3 & 5 & $1(20.0)$ & 1 & XXVId (1) \\
\hline & & & 16 & $4(25.0)$ & 4 & XXVId (2), XXVIc (1), XXVIe (1) \\
\hline $\begin{array}{l}\text { Water } \\
\text { buffalo }\end{array}$ & \multirow[t]{2}{*}{ Hunan ${ }^{1}$} & Yueyang & 4 & $1(25.0)$ & 1 & XXVIa (1) \\
\hline Total & & & 486 & $294(60.5)$ & $260(53.5)$ & $\begin{array}{l}\text { XXVIc (61), XXVIe (54), XXVIa (51), XXVIb (48), } \\
\text { XXVId (25), XXVIf (21) }\end{array}$ \\
\hline
\end{tabular}

${ }^{1}$ The DNA preparations of these samples were stored for more than three years before being used in the study.

\subsection{Sequence Analysis}

Positive secondary PCR products were sequenced bidirectionally on an ABI 3730 Genetic Analyzer at Sangon Biotech Co. (Shanghai, China). The raw sequences from each PCR product were assembled using the software Chromosol 1.5 (Technelysium Pty Ltd, Brisbane, Australia), and edited using the software BioEdit 7.05 (Bioedit Ltd, Manchester, UK). The sequences obtained were aligned with the reference sequence from the whole genome assembly using the software ClustalX 2.1 (Development supported by Science Foundation Ireland, http: / / www.clustal.org/, accessed on 6 May 2021). They were used to construct a maximum likelihood tree to assess their genetic relatedness using the software MEGA 7.0 (Development supported by National Institutes of Health (United States), https:/ / www.megasoftware.net/, accessed on 6 May 2021) and substitution rate was calculated on the basis of the general time-reversible model. The reliability of cluster formation was evaluated using the bootstrap method with 1000 replicates. The sequences in each well-supported cluster were considered as belonging to the same subtype family. Nucleotide sequence identity among subtype families was calculated using BioEdit 7.05 (Bioedit Ltd, Manchester, UK), and potential recombination events were identified on the basis of sequences of segregating sites (excluding insertions and deletions) using the software DnaSP 5.10 (Universitat de Barcelona, Barcelona, Spain). The nucleotide sequences were further translated into amino acid (AA) sequences and aligned with GP60 sequences of C. hominis, C. parvum, C. viatorum, C. ubiquitum, C. ryanae, and C. xiaoi using ClustalX 2.1. The signal peptide and glycosylphosphatidylinositol (GPI) anchor in GP60 sequence were predicted using PSORT II (http:/ / psort.hgc.jp/form2.html, accessed 
on 11 December 2020). N- and O- glycosylated sites were predicted using NetNGlyc 1.0 (http:/ / www.cbs.dtu.dk/services/NetNGlyc/, accessed on 11 December 2020) and YinOYang 1.2 (http:/ / www.cbs.dtu.dk/services/YinOYang/, accessed on 11 December 2020) servers, respectively. The furin cleavage site was predicted using ProP 1.0 (http: / / www.cbs.dtu.dk/services/ProP/, accessed on 11 December 2020).

\subsection{Nucleotide Sequence Accession Numbers}

The complete $g p 60$ gene of $C$. bovis and representative nucleotide sequences of 68 sequence types of the $C$. bovis gp60 gene obtained in this study were deposited in GenBank under the accession numbers MZ977132-MZ977200.

\subsection{Statistical Analysis}

The Chi-square test implemented in the software IBM SPSS Statistics 25 (International Business Machines Corp., Armonk, NY, USA) was used to compare differences in C. bovis subtype family occurrence between dairy cattle with or without diarrhea. Differences were considered significant when $p<0.05$.

\section{Results}

\subsection{Characteristics of the gp60 Gene of C. bovis}

The complete gp60 gene (GenBank No. MZ977200) was identified in contig_176 of the whole genome sequences of $C$. bovis. The coding region of the gene consisted of 1353 nucleotides encoding 450 amino acids. The GP60 of C. bovis had only $19.3-45.3 \%$ sequence identity to those of C. hominis (ACQ82748), C. parvum (AAF78281), C. viatorum (AJP62575), C. ubiquitum (XP_028874367), C. ryanae [23], and C. xiaoi (QXJ78680) (Figure 1). However, the GP60 of $C$. bovis possessed a signal peptide at the N-terminus and a glycosylphosphatidylinositol (GPI) anchor at the C-terminus, which are common in GP60 proteins of other Cryptosporidium species. A conserved amino acid sequence RSRR for the furin cleavage site was present between the GP40 and GP15 fragments of the protein. In the GP40 fragment of $C$. bovis, there was a polyglutamine tract encoded by CAA/CAG trinucleotide repeats, instead of the polyserine tract encoded by TCA/TCG/TCT trinucleotide repeats in C. parvum and C. hominis. Altogether, three potential N-glycosylation sites and 36 O-glycosylation sites were identified in the GP60 of C. bovis (Figure 1).

\subsection{Amplification Efficiency of the Subtyping Tool}

Altogether, 294 (60.5\%) of the 486 DNA preparations from C. bovis generated the expected gp60 PCR products, included 262 from dairy cattle, 27 from yaks, 4 from beef cattle, and one from water buffalo (Table 1). The amplification efficiency of the PCR using DNA preparations were stored for less than three years (samples from Heilongjiang, Hebei, Jiangsu, Yunnan, and Guangdong) $(77.7 \%$ or $181 / 233)$ was much higher than that using DNA preparations that were stored for a longer period (samples from Qinghai, Henan, Shanghai, and Hunan) (44.7\% or 113/253) (Table 1). Among the latter, 20 were randomly selected for re-analysis of the DNA using the SSU rRNA-based nested PCR [28], with only one being confirmed as still positive for C. bovis.

\subsection{Sequence Polymorphism in the C. bovis gp60 Gene}

Of the 294 gp60 PCR products, 260 were sequenced successfully using the secondary primers, which generated 68 sequence types, including one type identical to the reference from whole genome sequencing. Overall, nucleotide sequence differences of $0.1-49.3 \%$ were present among the sequence types. The sequence types differed from each other by both single nucleotide polymorphism (SNP) and length polymorphism (indel). The maximal difference in length among the sequence types was $138 \mathrm{bp}$. The SNPs and indel were scattered across the gp60 gene. 


\begin{tabular}{|c|c|c|c|c|c|c|c|c|c|}
\hline & 10 & 20 & 30 & 40 & 50 & 60 & 70 & 80 & 30 \\
\hline homi & RLSLIIVLL & SVIVSAVFSA & PAVPLRGTLKK & DV $\underline{\mathbf{S} V E G \underline{\mathbf{S S S S}}}$ & SSSSSSSSTV & & & & $-\mathrm{PA}$ \\
\hline c. viatorv & 2LTLIIVLL & SVIFSAVFSA & PAVPLRGTLK & DANLE- $\overline{\text { SSSS }}$ & TTTTTATTTT & & & & $-\overline{\mathrm{AA}}$ \\
\hline ryanae & KPLLLASLC & LAFLALVFSA & P-VPLRG $\underline{\mathbf{S}} L A$ & VRQSAV & $A G \underline{\mathbf{S}} Q G \underline{\mathbf{S}} Q \underline{\mathbf{T S}} \mathrm{A}$ & $Q P G \underline{\mathbf{T}} P G \underline{\mathbf{S}} V \underline{\mathbf{S}} Q$ & $\mathrm{P} \underline{\mathbf{T}} \mathrm{GAE} \underline{\mathbf{S}} \underline{\underline{T}} \mathrm{EV}$ & NDGKD & -EN $\underline{\mathbf{S}} \mathrm{D} \underline{\mathbf{S}} Q D G K$ \\
\hline xiaoi & RLPLYTLL & SALIALVLSA & PSVPLRG $\underline{\mathbf{S}} L \underline{\mathbf{S}}$ & $\underline{\mathbf{S}} S Q L G N \underline{\mathbf{S}} R \underline{\mathbf{S}} A$ & PAST & $\underline{\mathbf{T}}--\underline{\mathbf{T S}} G A D T D$ & $\underline{\underline{T} D A G S D S S R A}$ & EGEVDQTTVE & -GGSGKGEDS \\
\hline bovis & RLTLYITLL & SAFIALVLSA & PSVPLRGSLS & $\underline{\mathbf{T}} S Q P \mathbb{N} N \underline{\mathbf{S}} R \underline{\mathbf{S}} A$ & PPSSGAGDAA & $\mathrm{K}--\mathrm{A} \underline{\mathrm{S}} \mathrm{A} A \mathrm{EVE}$ & QEASEEESQV & TSEAGNVVQS & TSGSEAQETP \\
\hline
\end{tabular}

C. hominis
C. parvum
C. viatorum
C. ubiquitum
C. ryanae
C. xiaoi
C. bovis

100

110

120

130

140

150

160

170

180

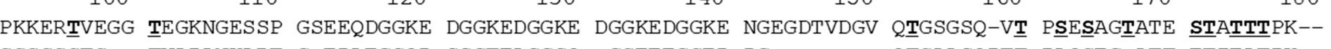
SSSSSSTS-- TVAPANKART G-EDAEGSQD SSGTEASGSQ -GSEEEGSED DG------- QTSAASQPTT PAQSEG-ATT ETIEATPK-PKK------ VAARATGEEE AHEDVQESQD GQGTE----- --EGTTPTAP-- TTTPSTTAPT AAPTTVSTTA PSGSGVDPTS TDGDEKTDTD TG--.-- - - ENSNNVSSGQ GVAQESSD

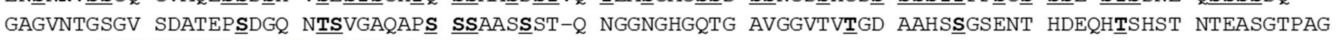

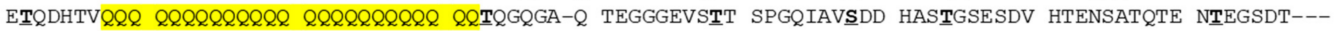

\section{C. hominis \\ c. parvom \\ c. viatorum \\ c. ubiquitum \\ c. ryanae \\ C. xiaoi \\ c. bovis}

$$
\text { DS }
$$

190

200

210

220

230

240

250

260

270

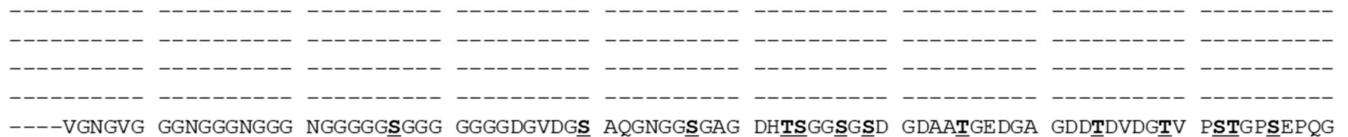

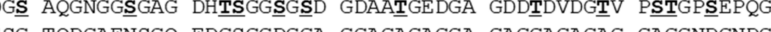

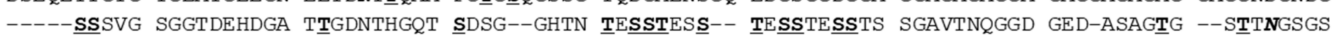

C. hominis
C. parvum
C. viatorum
C. ubiquitum
C. ryanae
C. xiaoi
C. bovis

$\begin{array}{llllllll}280 & 290 & 300 & 310 & 320 & 330 & 340 & 350\end{array}$ -------EE CGTSFVMWFE KGTPVATLKC GDYTIVYAPI KDQTDPAPRY ISGEVTSVSF EKSESTVTIK VNGKEFSTLLS ANSSSPTKDN --------EE CGTSFVMWFG EGTPAATLKC GAYTIVYAPI KDQTDPAPRY ISGEVTSVTF EKSDNTVKIK VNGQDFSTLS ANSSSPTENG

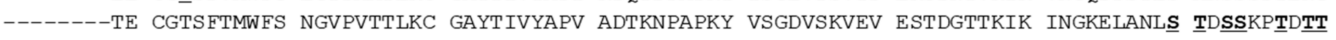
-------MEK CGTSFVMWFV SGVPVTTLEC GSYTMVYGPV ENETNPAARY VSGTVTTVTY DASN--KKLM VNNQEFATLS TDSSQPTTAT

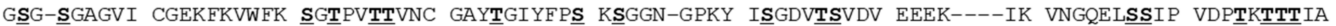
NDGS $\underline{\underline{S}}$ TAPVV CGEKFVVWFS DGVPVTTVSC GKYTGIYYPS ADGNP-GPKY ISGEVTAVVV EEGK----IK VNNQELSTIS VTPNEN

c. bovis QDGPANSTVV CGEKFTIWFS GGVPVTTVDC GAYTGIYYPT T्TSGG-EPKY TSETVTDVKV ENNV-----IK VNNKDLSSIS VTSG------

\section{c. hominis \\ c. parvom \\ c. viatorum \\ c. ubiquitum \\ c. ryanae \\ c. $\mathbf{x i a o i}$ \\ c. bovis}

\begin{tabular}{|c|c|c|c|c|c|c|c|c|}
\hline 370 & 380 & 390 & 400 & 41 & 420 & 430 & 440 & \\
\hline GES------- & --- & --- & ---- & $------\mathrm{SDSH}$ & VQSRSRRSLA & EEN-- & GETVATVDLF & \\
\hline G---------- & --- & -- & -- & $----\underline{\mathbf{S}} \mathrm{AGQ}$ & ASSRSRRSLS & EET-- & SEAAATVDLF & \\
\hline$\underline{\mathbf{T}}---$ & -- & -- & -- & $-----E \underline{\mathbf{S}} \mathrm{L}$ & $\underline{\mathbf{S}} R \underline{\underline{S}} \underline{I V K R} \mathrm{SL} L_{-}$ & EEA-- & --VQATSDVF & $\mathrm{FAF}$ \\
\hline -------- & --- & ----- & ---- & $----\infty--$ & A--PAARLLA & EDTVTEA- & ---VTMTDLY & Y T \\
\hline TSTVSTATTT & ETSTTSETST & PTSSPSTTAS & QDAEEDEEDE & EEAAVAAAAK & 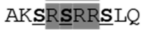 & EEGQEEGREE & $\underline{\mathbf{S}} Q \underline{T} T E I A D V Y$ & Y \\
\hline & & $--G D D S V \underline{\underline{S}} A A$ & AASKGT的DK-- & $--------S$ & AKSRSRRSLQ & QG------TE & NQTTEVVDVY & Y SF \\
\hline . & & $--A A$ & GEAEG----- & $---------V$ & ARSRSRRSLQ & EE-------E & -TVTEIVDAY & \\
\hline 460 & 470 & 480 & 490 & 500 & 510 & 520 & 530 & \\
\hline EVAVPKDENA & DKRSEYSLVA & DDKPFYTG-- & ANSGITNGVY & KLDENGNLVD & KDNEVLLKDA & G--SSAFG & YIVPSVEAIF & $\mathrm{F}$ AA \\
\hline EVAVPNVEDA & SKRDKYSLVA & DDKPFYTG-- & ANSGTTNGVY & RLNENGDLVD & KDNTVLLKDA & $\mathrm{G}-\mathrm{SSAFG}$ & YIVPSVFAIF & $\overline{\mathrm{F} A \mathrm{AAL}}$ \\
\hline EVAVPNDSDS & NKRDKYSLVS & NDKTFYTG-- & TNSGAADGVF & KINKNGDLVD & KDSNVVLKDA & S-SSSAFG & YIIPSVEAIF & $\overline{\mathrm{F} A A F I}$ \\
\hline SVGVPANQDE & SKRDKYSLSA & DNQVFYTGTA & SNSGVTSGIF & KLNENGDLVD & PSNTVVLKDA & D--SAAFGER & YIIPSVFAIF & F AAFI \\
\hline VVKLPKEESA & DKRNKYML-A & DSDGDVIFE- & --GSKEQEEF & KFDDKGDLLD & SEGKVILAND & SGSSSAFGYR & YVIPSILAFI & I LTVF \\
\hline SVKLPNEKEA & EKRNKYFL-A & DDGGDVIFE- & --GNK-KEEF & HFDGEGDLLD & SEGKVILES- & GDSSSAFDLK & YIIPSISAFV & $\mathrm{V}$ LSIL \\
\hline VVRLPKS $\underline{\underline{S}} E D A$ & GKRNKYIL-A & DDGGDAIFE- & --GTG-KEEF & HYDDKGDLLD & SKGDVILEG- & GGTSSAFG & YIIPSISAFI & I LSIL \\
\hline
\end{tabular}

Figure 1. Alignment of the full GP60 sequence from Cryptosporidium bovis (this study) with those from C. hominis (ACQ82748), C. parvum (AAF78281), C. viatorum (AJP62575), C. ubiquitum (XP_028874367), C. ryanae [23], and C. xiaoi (QXJ78680). The signal peptide at the N-terminus and GPI anchor at the C-terminus are shaded in green and red, respectively. The putative furin cleavage site is shaded in gray. Potential N-linked glycosylation sites are marked in bold and italics, and O-linked glycosylation sites in bold with underline. The unique polyglutamine tract in C. bovis is highlighted in yellow. Dashes indicate amino acid deletions.

\subsection{Nomenclature and Phylogenetic Relationship of C. bovis Subtype Families}

On each farm, one representative of each gp60 sequence type was used in phylogenetic analysis. The 90 sequences selected formed six reliable clusters in a maximum likelihood tree. According to the nomenclature of gp60 subtype families, each cluster was designated as a subtype family and named as XXVIa, XXVIb, XXVIc, XXVId, XXVIe, and XXVIf (Figure 2). Among them, XXVIa and XXVIb formed a group divergent from the other group formed by the other four subtype families. In agreement with this, the nucleotide identity between XXVIa/XXVIb and other subtype families was low (50.7-59.9\%) (Table 2). The nucleotide differences among the subtype families included SNPs and indels across the entire gp60 sequences. However, sequences at the $5^{\prime}$ and $3^{\prime}$ ends were more conserved among the subtype families. For examples, XXVIb had a high sequence identity to XXVIe 
and XXVIc at the $5^{\prime}$ and $3^{\prime}$ end of the sequence, respectively. XXVIe was very similar to $X X V I f$ at the $3^{\prime}$ end of the sequence. This suggested the occurrence of genetic recombination among subtype families. In a DnaSP analysis, 121 potential recombination events were identified among all the six subtype families. At the amino acid level, sequence polymorphism among six of the subtype families was most obvious in the N-terminus of the GP40 fragment (Figure 3). In contrast, sequences were more conserved at the C-terminus of GP40 and the entire GP15 region. Except for XXVIa, the other subtype families did not have a polyglutamine tract encoded by CAA/CAG in GP40.

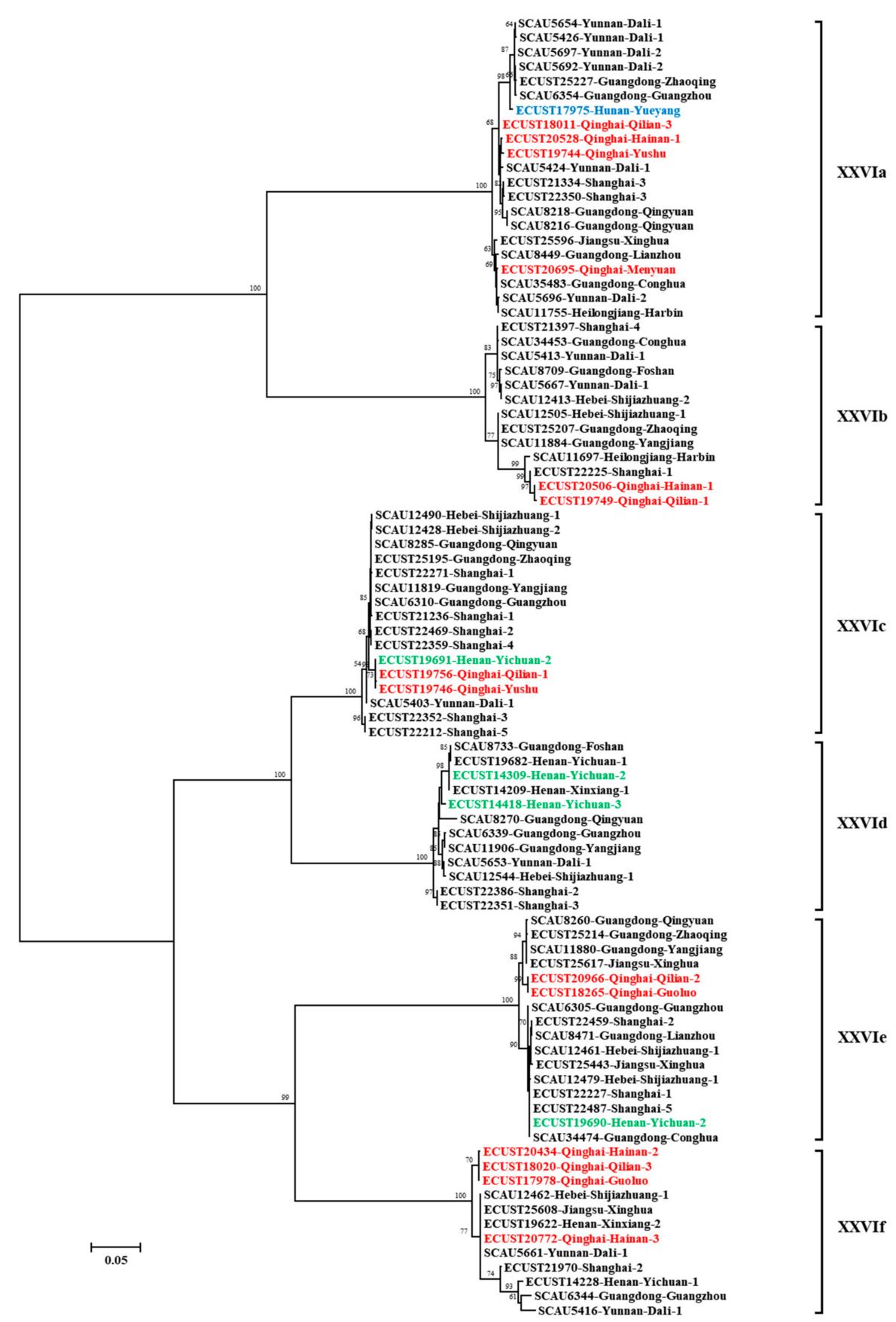

Figure 2. Phylogenetic relationship among six Cryptosporidium bovis subtype families (XXIVa-XXIVf) inferred by a maximum likelihood analysis of partial sequences of the gp60 gene. Sequences from dairy cattle, beef, yaks, and water buffalo are indicated by black, green, red, and blue characters, respectively. Bootstrap values greater than $50 \%$ from 1000 replicates are shown on branches. The scale bar equals 5 nucleotide substitutions per 100 nucleotides. 
Table 2. Percent nucleotide sequence identity among Cryptosporidium bovis subtype families at the gp60 locus.

\begin{tabular}{lcccccc}
\hline & XXVIa & XXVIb & XXVIc & XXVId & XXVIe & XXVIf \\
\hline XXVIa & - & & & & & \\
XXVIb & $54.9-59.6$ & - & & & & \\
XXVIc & $51.4-53.9$ & $56.5-59.9$ & - & & & \\
XXVId & $53.7-56.7$ & $52.1-56.3$ & $75.3-77.7$ & - & & \\
XXVIe & $51.2-54.3$ & $52.1-57.1$ & $59.2-64.4$ & $58.1-62.3$ & - & \\
XXVIf & $50.7-54.0$ & $51.9-55.1$ & $62.1-65.8$ & $58.0-62.6$ & $62.8-65.8$ & - \\
\hline
\end{tabular}

10

XXVIa

XXVIb

XXVIC

XXVId

XXVIe

XXVIf

XXVIa

XXVIb

XXVIc

XXVId

XXVIe

XXVIf

XXVIa

XXVIb

XXVIC

XXVId

XXVIe

XXVIf

XXVIa

XXVIb

XXVIc

XXVId

XXVIe

XXVIf

XXVIa

XXVIb

XXVIc

XXVId

XXVIe

XXVIf

XXvIa

XXVIb

XXVIc

XXVId

XXVIe

XXVIf

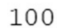

370

20

30

40

50

60

70

80

90

VCSLLRG

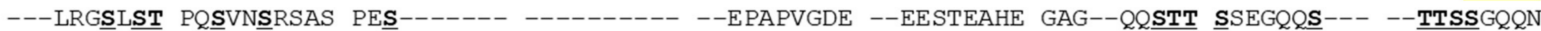

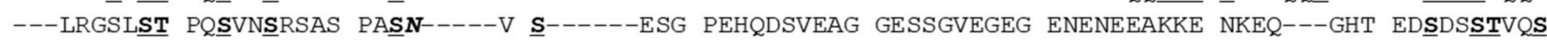

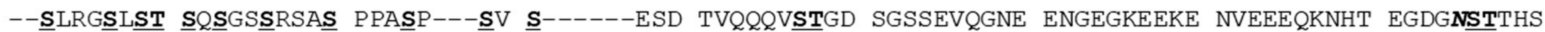

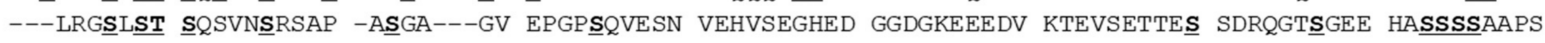

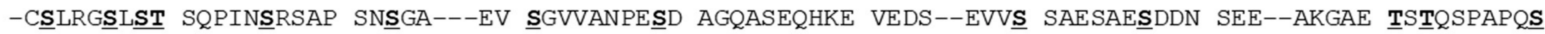

110

120

130

140

150

160

170

180

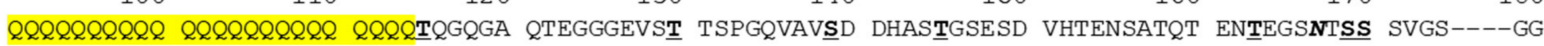
QNQSQSQQEH QAGTEAGNSA GVSSTQNTGG DGHTSGSSDS NHDSSTGATG HTPSTDDATQ VQGAGGDDHS TSTDSTSQPT SSGS----ES

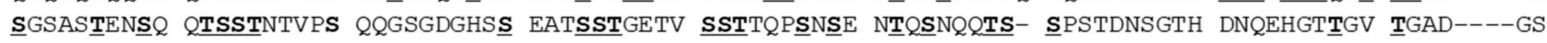

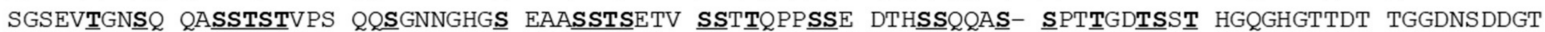

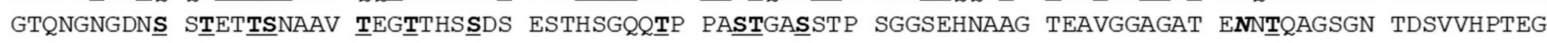

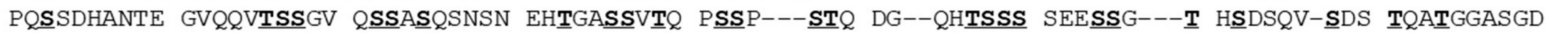

$\begin{array}{llllllll}190 & 200 & 210 & 220 & 230 & 240 & 250 & 260\end{array}$

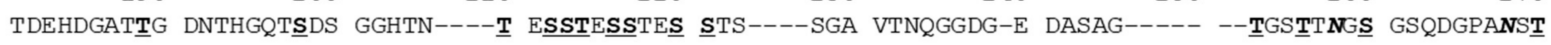

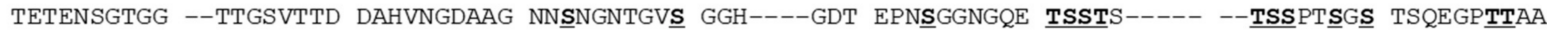
ESTTDQAAPG ----GTSSEP GSATEDDATD NSTQGATTPE AGN----QDE STTHGSAGGN DQG------- -DE--SGGSG ADNGGS-TTA

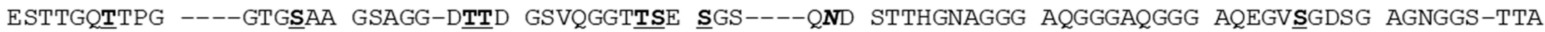
QEGETETEAT QTAPGTGG-Q GSSTTQDGAG DNI $Q$ GSSTTQ DGAGTGGQGS STTQDGAGDN SQGDG----- -SGGGGAGND AGNDGSGTAG ENSTHQTGPG STVPGTDSTV GEESGADNTQ ESTPGTGGGH SGSGDQVDGD HNEHETQGSN GNNGQ----- -EGGSSDNGG TGNGDSVTNA

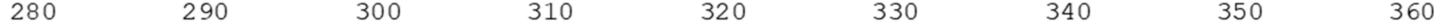
VVCGEKFTIW FSGG-VPVTT VDCGAYTGIY YPTANGG-GE PKYTSETVT⿱一𫝀D VKVENSVIKV NNKDLSSISV TS------GA AGEAEG----

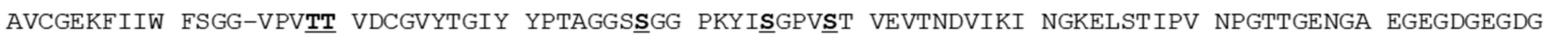

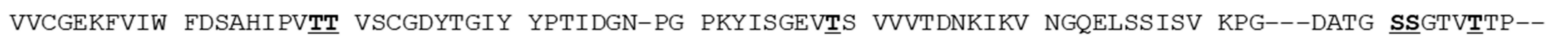
VVCGEKFVIW FDSGRIPVTT VSCGDYTGIY YPTIDGD-SG PKYISGTVDS VSVTDNKISV NGKELSSISV KPG---DTAG SSVAATIP--

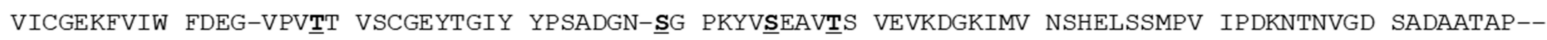

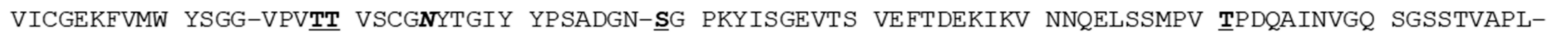
380 390

410

420

430

440

450

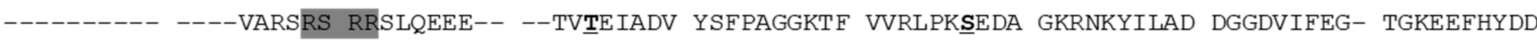
ESGKGEEGEE AEEVVAKSRS RRSLQDEE-- --AVTQIADA YSFPAGGKTL TVKLPKEADA KKREKYMLAD DRGDIIFEG- NKKEEFNFND --------E GA $\underline{\underline{S}} E$ GAKSRS RRSLQEEV-- --LATEIADA YSFPAGGKTL TVKLPKEAEA DKREKYMLAD DRGDIIFEG- TKKEEFNFND -------E AAGGGAKSRS RRSLQEEV-- --AATEIVDA YSFPAGGKTF VVRLPKDEDA EKRNKYILAD DGGDVIFEG- TDKEEFHYDD

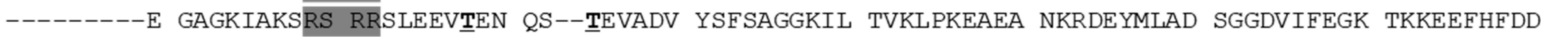
--------E DAGKSAKSRS RRSLQEEAQE EAVV

460463

KGDLLD

KGDLLD吕N- ---

KGDLLNQKAK ---

KGDLLD---- ---

KGNLFD $\underline{\mathbf{s}} Q \mathrm{NH}$

KGNLFDSQNH VYW

Figure 3. Alignment of partial amino acid sequences of GP60 from six Cryptosporidium bovis subtype families. The putative furin cleavage site is shaded in gray. Potential N-linked glycosylation sites are marked in bold and italics, and O-linked glycosylation sites in bold with underline. The unique polyglutamine tract in XXIVa is highlighted in yellow. Dashes indicate amino acid deletions, except those at the $\mathrm{N}$ - and C-termini of the sequences. 


\subsection{Distribution of Subtype Families by Host and Age}

The six subtype families were all identified in dairy cattle in the order of XXVIc (55), XXVIe (50), XXVIb (45), XXVIa (44), XXVId (23), and XXVIf (12). In yaks, five of the six subtype families were detected, with XXVId absent (Table 1). The dominant subtype family in yaks was XXVIf (9/26), which was less common (12/229) in dairy cattle. In beef cattle, three subtype families were obtained from the four successfully subtyped samples, including XXVId (2), XXVIc (1), and XXVIe (1). The single sample from the water buffalo subtyped belonged to XXVIa.

Overall, the six subtype families were found in pre-weaned as well as in post-weaned dairy calves. However, on a particular farm, the distribution of subtype families in preweaned dairy calves appeared different from that in post-weaned dairy calves (Table 3 ). On Farm Dali-1, pre-weaned dairy calves were infected by XXVIb (6), XXVIf (4), XXVId (2), and XXVIa (1). However, in post-weaned dairy calves on the farm, XXVIf and XXVId disappeared, while XXVIc (4) emerged. Subtype family alteration was also observed on Farms Shijiazhuang-1, Xinghua, Guangzhou, and Yangjiang (Table 3). On some other farms, including Shanghai-1, Shanghai-4, and Foshan, the subtype families switched completely between pre-weaned and post-weaned dairy calves (Table 3 ).

Table 3. Distribution of Cryptosporidium bovis subtype families at the gp60 locus in pre- and post-weaned dairy calves on study farms.

\begin{tabular}{|c|c|c|c|c|}
\hline \multirow[b]{2}{*}{ Farm } & \multicolumn{2}{|c|}{ Pre-Weaned Dairy Calves } & \multicolumn{2}{|c|}{ Post-Weaned Dairy Calves } \\
\hline & $\begin{array}{c}\text { No. of Samples } \\
\text { Subtyped }\end{array}$ & Subtype Family (No. of Samples) & $\begin{array}{c}\text { No. of Samples } \\
\text { Analyzed }\end{array}$ & Subtype Family (No. of Samples) \\
\hline Harbin & 9 & XXVIa (8), XXVIb (1) & - & \\
\hline Shijiazhuang-1 & 1 & XXVId (1) & 6 & XXVIb (3), XXVId (2), XXVIc (1) \\
\hline Shijiazhuang-2 & 4 & XXVIb (3), XXVIc (1) & - & \\
\hline Yichuan-1 & - & & 1 & XXVId (1) \\
\hline Xinxiang-1 & 1 & XXVId (1) & - & \\
\hline Xinxiang-2 & 1 & XXVIf (1) & - & \\
\hline Xinghua & 1 & XXVIe (1) & 5 & XXVIa (3), XXVIe (2) \\
\hline Shanghai-1 & 35 & XXVIc (35) & 2 & XXVIb (1), XXVIe (1) \\
\hline Shanghai-2 & 8 & $\begin{array}{c}\text { XXVId (5), XXVIc (1), XXVIf (1), } \\
\text { XXVIe (1) }\end{array}$ & - & \\
\hline Shanghai-3 & 7 & XXVIa (4), XXVIc (2), XXVId (1) & - & \\
\hline Shanghai-4 & 7 & XXVIb (7) & 1 & XXVIc (1) \\
\hline Shanghai-5 & 3 & XXVIc (2), XXVIe (1) & - & \\
\hline Dali-1 & 13 & $\begin{array}{c}\text { XXVIb (6), XXVIf (4), XXVId (2), } \\
\text { XXVIa (1) }\end{array}$ & 10 & XXVIc (4), XXVIa (3), XXVIb (3) \\
\hline Dali-2 & 9 & XXVIa (9) & - & \\
\hline Zhaoqing & 17 & $\begin{array}{c}\text { XXVIe (12), XXVIc (3), XXVIa (1), } \\
\text { XXVIb (1) }\end{array}$ & - & \\
\hline Guangzhou & 9 & XXVIe (8), XXVIc (1) & 8 & $\begin{array}{l}\text { XXVIf (3), XXVId (2), XXVIe (2), } \\
\text { XXVIa (1) }\end{array}$ \\
\hline Yangjiang & 12 & XXVIe (6), XXVIb (3), XXVIc (3) & 5 & XXVIb (2), XXVIe (2), XXVId (1) \\
\hline Foshan & 14 & XXVIb (14) & 1 & XXVId (1) \\
\hline Qingyuan & - & & 12 & $\begin{array}{l}\text { XXVId (6), XXVIa (3), XXVIe (2), } \\
\text { XXVIc (1) }\end{array}$ \\
\hline Conghua & 11 & XXVIe (8), XXVIa (2), XXVIb (1) & - & \\
\hline Lianzhou & 8 & XXVIa (6), XXVIe (2) & - & \\
\hline Total & 170 & $\begin{array}{l}\text { XXVIc (48), XXVIe (39), XXVIb (36), } \\
\text { XXVIa (31), XXVId (10), XXVIf (6) }\end{array}$ & 51 & $\begin{array}{l}\text { XXVId (13), XXVIa (10), XXVIe (9), } \\
\text { XXVIb (9), XXVIc (7), XXVIf (3) }\end{array}$ \\
\hline
\end{tabular}

\subsection{Distribution of C. bovis Subtype Families by Farm and Location}

One to five subtype families were identified on each of the 33 study farms, with nine farms having one subtype family, 12 farms having two, five farms having three, four farms having four, and three farms having five (Table 1). On the farms with one subtype family, 
only one to three samples were successfully subtyped, with the exception of Farm Dali-2 where nine samples were subtypes. In contrast, farms with multiple subtype families mostly had reasonable numbers of samples subtyped. Among the farms with one or two subtype families, some had the same distribution of subtype families, such as Farms Dali-2, Menyuan and Yueyang, which all had only XXVIa. On the farms with three or more subtype families, the distribution of $C$. bovis subtype families varied by farm (Table 1 ).

In each province, one to six subtype families were identified (Table 4). In Shanghai and Guangdong, all six subtype families were observed. However, the subtype family distribution in these two provinces was different, with XXVIc (41/63) being dominant in Shanghai and XXVIe (42/97) being dominant in Guangdong. A similar situation was observed in the provinces with five subtype families (Hebei, Qinghai, and Yunnan). One to four subtype families were present in Hunan, Jiangsu, Heilongjiang, and Henan.

Table 4. Distribution of Cryptosporidium bovis subtype families at the gp60 locus by location in China.

\begin{tabular}{|c|c|c|c|}
\hline Host & Province & No. of Samples Subtyped & Subtype Family (No. of Samples) \\
\hline \multirow{7}{*}{ Dairy cattle } & Heilongjiang & 9 & XXVIa (8), XXVIb (1) \\
\hline & Hebei & 14 & XXVIb (6), XXVId (3), XXVIe (2), XXVIc (2), XXVIf (1) \\
\hline & Henan & 4 & XXVId (2), XXVIf (2) \\
\hline & Jiangsu & 10 & XXVIa (6), XXVIe (3), XXVIf (1) \\
\hline & Shanghai & 63 & 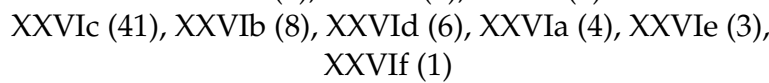 \\
\hline & Yunnan & 32 & XXVIa (13), XXVIb (9), XXVIc (4), XXVIf (4), XXVId (2) \\
\hline & Guangdong & 97 & $\begin{array}{c}\text { XXVIe (42), XXVIb (21), XXVIa (13), XXVId (10), XXVIc } \\
\text { (8), XXVIf (3) }\end{array}$ \\
\hline Yak & Qinghai & 26 & XXVIf (9), XXVIa (6), XXVIc (5), XXVIb (3), XXVIe (3) \\
\hline Beef cattle & Henan & 4 & XXVId (2), XXVIc (1), XXVIe (1) \\
\hline Water buffalo & Hunan & 1 & XXVIa (1) \\
\hline Total & - & 260 & $\begin{array}{l}\text { XXVIc (61), XXVIe (54), XXVIa (51), XXVIb (48), XXVId } \\
\text { (25), XXVIf (21) }\end{array}$ \\
\hline
\end{tabular}

\subsection{Corrlation between C. bovis Subtype Families and Diarrhea Occurance in Dairy Cattle}

Of the 373 fecal samples with data on fecal consistency, 214 were subtyped, including those from cattle with no diarrhea $(n=149)$, moderate diarrhea $(n=43)$, and watery diarrhea $(n=22)$ (Table 5). All six subtype families were observed in the three groups of dairy cattle. However, the frequency of XXIVd in dairy cattle with moderated diarrhea $(18.6 \%, 8 / 43)$ was significantly higher than that in dairy cattle with no diarrhea $(6.7 \%$, $\left.10 / 149 ; \chi^{2}=0.018, p=0.018\right)$. In contrast, for the other five subtype families, the frequency of the subtype family in cattle with no diarrhea was not significantly different form that in dairy cattle with moderated diarrhea and watery diarrhea, respectively (Table 5).

Table 5. Difference in the frequency of Cryptosporidium bovis subtype families in dairy cattle with different diarrhea statues.

\begin{tabular}{|c|c|c|c|c|c|c|c|c|c|}
\hline \multirow{2}{*}{$\begin{array}{l}\text { Subtype } \\
\text { Family }\end{array}$} & \multirow{2}{*}{$\begin{array}{l}\text { No. of Samples } \\
\text { Subtyped }\end{array}$} & \multirow{2}{*}{$\begin{array}{l}\text { No. of Samples } \\
\text { without Diarrhea }\end{array}$} & \multicolumn{4}{|c|}{ Moderate Diarrhea } & \multicolumn{3}{|c|}{ Watery Diarrhea } \\
\hline & & & $n$ & $x^{2}$ & OR $(95 \% \text { CI })^{1}$ & $p$ & $x^{2}$ & OR $(95 \% \mathrm{CI})$ & $p$ \\
\hline XXVIa & 44 & 35 & 6 & 1.807 & $\begin{array}{c}0.528 \\
(0.206-1.355)\end{array}$ & 0.179 & 1.077 & $\begin{array}{c}0.514 \\
(0.144-1.841)\end{array}$ & 0.299 \\
\hline XXVIb & 31 & 22 & 8 & 0.373 & $\begin{array}{c}1.319 \\
(0.541-3.218)\end{array}$ & 0.541 & 1.720 & $\begin{array}{c}0.275 \\
(0.035-2.149)\end{array}$ & 0.190 \\
\hline XXVIc & 55 & 33 & 15 & 2.887 & $\begin{array}{c}1.883 \\
(0.901-3.934)\end{array}$ & 0.089 & 1.000 & $\begin{array}{c}1.640 \\
(0.618-4.357)\end{array}$ & 0.317 \\
\hline XXVId & 22 & 10 & 8 & 5.556 & $\begin{array}{c}3.177 \\
(1.168-8.644)\end{array}$ & $0.018^{2}$ & 3.355 & $\begin{array}{c}3.089 \\
(0.877-10.881)\end{array}$ & 0.067 \\
\hline XXVIe & 50 & 41 & 5 & 4.624 & $\begin{array}{c}0.347 \\
(0.128-0.942)\end{array}$ & 0.032 & 0.861 & $\begin{array}{c}0.585 \\
(0.187-1.833)\end{array}$ & 0.353 \\
\hline XXVIf & 12 & 8 & 1 & 0.692 & $\begin{array}{c}0.420 \\
(0.051-3.452)\end{array}$ & 0.406 & 2.177 & $\begin{array}{c}2.783 \\
(0.679-11.407)\end{array}$ & 0.140 \\
\hline Total & 214 & 149 & 43 & - & - & - & - & - & - \\
\hline
\end{tabular}

\footnotetext{
${ }^{1}$ OR: odds ratio; CI: confidence interval. ${ }^{2}$ Significant $p$ value $<0.05$.
} 


\section{Discussion}

In this study, we identified the gp60 gene from a published genome of $C$. bovis and established a gp60-based subtyping tool. Using the tool, a highly genetic diversity was revealed in C. bovis from dairy cattle, beef cattle, yaks, and water buffalos. The data obtained suggest that there could be potential differences in C. bovis subtypes between pre-weaned and post-weaned dairy cattle.

Results of comparative analysis indicate that $C$. bovis is significantly different from other Cryptosporidium species at the gp60 gene. The length of gp60 gene in C. bovis was $\sim 1353 \mathrm{bp}$, which is much longer than those in C. parvum, C. hominis, C. meleagridis, and other species (873-1089 bp) [21,29-33], but similar to those in the genetically related C. xiaoi ( $1437 \mathrm{bp}$ ) and C. ryanae ( 1548 bp) [18,22]. Although the GP60 of C. bovis is structurally similar to those of other species, its sequences for the $\mathrm{N}$-terminal signal peptide and Cterminal GPI anchor are unique. This makes it difficult to use the gp60 primers for other species, which are generally based on sequences in the two regions, to amplify the gp60 gene of $C$. bovis by PCR. In addition, a large number of SNPs are present in the gp 40 fragment between C. bovis and other Cryptosporidium species (Figure 1). Since GP40 targets host cell receptors during sporozoite invasion, the sequence differences in GP40 fragment could contribute to biological differences between C. bovis and other species [21].

The gp60 PCR assay developed here could be used in studies of the transmission of C. bovis. In the study, 294 of 486 C. bovis-positive DNA preparations produced expected amplicons using the gp 60 PCR we developed. The overall amplification efficiency of the PCR is $60.5 \%$. The true amplification efficiency could be much higher, as some DNA preparations used might have degraded during long storage. This was supported by the greatly reduced amplification efficiency of the PCR $(44.7 \%)$ when DNA preparations stored for more than three years were used in PCR. The 20 randomly selected gp 60 PCR-negative DNA preparations were mostly negative for Cryptosporidium in the re-analysis of the DNA using an SSU rRNA-based PCR. Importantly, a high genetic diversity was observed within C. bovis in sequence analysis of the gp 60 PCR products, producing 68 sequence types from 260 samples. Therefore, the gp60 subtyping tool has high resolution, thus could be effective in genetic characterization of $C$. bovis.

The high genetic diversity within C. bovis is likely due to the wide occurrence of genetic recombination. In addition to the numerous SNPs among the six subtype families identified, mosaic sequences were observed, especially among XXVIb, XXVIc, and XXVIe. The 121 potential recombination events in the obtained gp60 sequences further supported the occurrence of frequent genetic recombination at the locus in C. bovis. The high prevalence and long duration of $C$. bovis infection and frequent occurrence of multiple subtype families on a single farm could greatly facilitate the occurrence of genetic recombination among isolates, leading to the emergence of new subtypes. This was in agreement with the observations in C. xiaoi and C. ryanae [18,22]. Several studies on other Cryptosporidium species also indicated the frequent genetic recombination at the gp60 locus [34,35].

No clear host adaption was observed within C. bovis. All six subtype families of $C$. bovis have been observed in dairy cattle. These subtype families have been mostly identified in other bovine animals. In yaks, only five subtype families were observed, but the number of samples examined was small and the absent subtype family XXVId was detected in beef cattle. In addition, the other two subtype families detected in beef cattle (XXVIc and $X X V I e)$ are common subtype families in dairy cattle. The only subtype family in water buffalo, XXVIa, is also common in dairy cattle and yaks. Thus, no obvious differences were observed in the distribution of $C$. bovis gp 60 subtype by host. This was different from the observations in other Cryptosporidium species, including the genetically related C. xiaoi and C. ryanae $[18,22,36]$.

Differences in the transmission dynamics of $C$. bovis among geographic locations are not obvious currently. Among the three provinces with significant numbers of $C$. bovis samples (Yunnan, Shanghai, and Guangdong), the dominant subtype families identified were mostly similar (Table 4). In Yunnan, the dominant one among the five identified 
subtype families was XXVIa, which was identified at reasonable frequency in Guangdong and Shanghai. Although the most commonly identified subtype family in Guangdong, XXVIe, was not detected in dairy cattle in Yunnan, it has been detected in Shanghai and other areas. The lack of geographic segregation of subtype families is expected in view of the high prevalence of $C$. bovis and frequent genetic recombination at this locus.

There could be age-associated differences in the distribution of $C$. bovis subtype families on farms. On some farms, the dominant subtype family in pre-weaned calves disappeared or became less common in post-weaned calves. Accordingly, there were usually some new subtype families appearing in the post-weaned calves on these farms. As GP60 is an immunodominant antigen involved in the invasion of Cryptosporidium spp., the changes in gp60 subtype families between young and older calves could reflect the existence of subtype-specific immunity after an initial episode of $C$. bovis infection. Further studies involving longitudinal sampling of animals and subtyping of isolates from sequential episodes are needed to resolve this important issue.

Cryptosporidium bovis subtype families may have different degrees of associations with diarrhea. As indicated by results of the $\chi^{2}$ analysis, five of the six $C$. bovis subtype families were not significantly associated with moderate or watery diarrhea in dairy cattle. This was expected, as C. bovis infection had no obvious association with diarrhea in dairy cattle in most previous studies $[13,25,37]$. However, in the present study, the frequency of XXVId was significantly higher in dairy cattle with moderate diarrhea. This supports the observation in a few studies that $C$. bovis has modest pathogenicity in dairy cattle [38,39].

\section{Conclusions}

We identified the gp60 sequence of $C$. bovis and developed a subtyping tool for the pathogen on the basis of the sequence acquired. Using the tool, we showed a high genetic diversity within C. bovis, and a lack of host-associated differences in the distribution of the six subtype families were identified. The distribution of subtype families on a farm could be different between pre- and post-weaned calves, due to possible subtype-specific immunity. Future studies using more samples from different regions and hosts and sequence analyses of additional genetic loci are needed to further characterize the genetic diversity and transmission dynamics of $C$. bovis.

Author Contributions: Conceptualization, Y.F. and Y.G.; methodology, W.W., L.X., Y.F. and Y.G.; validation M.W., F.Y. and N.L.; formal analysis, W.W., M.W. and N.L.; investigation, W.W. and F.Y.; resources, W.W., M.W. and F.Y.; data curation, W.W. and Y.G.; writing original draft preparation, W.W.; writing review and editing, all co-authors; visualization, W.W., M.W. and Y.G.; supervision, Y.F. and Y.G.; project administration, Y.F. and Y.G.; funding acquisition, Y.F. and Y.G. All authors have read and agreed to the published version of the manuscript.

Funding: This research was funded by National Natural Science Foundation of China, grant numbers 31972697 and U1901208; Natural Science Foundation of Guangdong Province, grant number 2019A1515011979; 111 Project, grant number D20008; and Innovation Team Project of Guangdong Universities, grant number 2019KCXTD001. The APC was funded by South China Agricultural University.

Institutional Review Board Statement: Not applicable.

Informed Consent Statement: Not applicable.

Data Availability Statement: The representative nucleotide sequences obtained in this study are openly available in GenBank under the accession numbers MZ977132-MZ977200.

Conflicts of Interest: The authors declare no conflict of interest. The funders had no role in the design of the study; in the collection, analyses, or interpretation of data; in the writing of the manuscript, or in the decision to publish the results. 


\section{References}

1. Khan, A.; Shaik, J.S.; Grigg, M.E. Genomics and molecular epidemiology of Cryptosporidium species. Acta Trop. 2018, 184, 1-14. [CrossRef] [PubMed]

2. Mmbaga, B.T.; Houpt, E.R. Cryptosporidium and Giardia infections in children: A review. Pediatr. Pediatric Clin. 2017, 64, 837-850. [CrossRef] [PubMed]

3. Santin, M. Cryptosporidium and Giardia in ruminants. Vet. Clin. N. Am. Food Anim. Pract. 2020, 36, 223-238. [CrossRef] [PubMed]

4. Zhang, Z.; Hu, S.; Zhao, W.; Guo, Y.; Li, N.; Zheng, Z.; Zhang, L.; Kvac, M.; Xiao, L.; Feng, Y. Population structure and geographical segregation of Cryptosporidium parvum IId subtypes in cattle in China. Parasites Vectors 2020, 13, 425. [CrossRef]

5. Li, N.; Wang, R.; Cai, M.; Jiang, W.; Feng, Y.; Xiao, L. Outbreak of cryptosporidiosis due to Cryptosporidium parvum subtype IIdA19G1 in neonatal calves on a dairy farm in China. Int. J. Parasitol. 2019, 49, 569-577. [CrossRef]

6. Niine, T.; Dorbek-Kolin, E.; Lassen, B.; Orro, T. Cryptosporidium outbreak in calves on a large dairy farm: Effect of treatment and the association with the inflammatory response and short-term weight gain. Res. Vet. Sci. 2018, 117, 200-208. [CrossRef]

7. Brar, A.P.S.; Sood, N.K.; Kaur, P.; Singla, L.D.; Sandhu, B.S.; Gupta, K.; Narang, D.; Singh, C.K.; Chandra, M. Periurban outbreaks of bovine calf scours in Northern India caused by Cryptosporidium in association with other enteropathogens. Epidemiol. Infect. 2017, 145, 2717-2726. [CrossRef]

8. Randhawa, S.S.; Zahid, U.N.; Singla, L.D.; Juyal, P.D. Drug combination therapy in control of cryptosporidiosis in Ludhiana district of Punjab. J. Parasit. Dis. 2012, 36, 269-272. [CrossRef]

9. Ralston, B.; Thompson, R.; Pethick, D.; McAllister, T.; Olson, M. Cryptosporidium andersoni in Western Australian feedlot cattle. Aust. Vet. J. 2010, 88, 458-460. [CrossRef]

10. Esteban, E.; Anderson, B.C. Cryptosporidium muris: Prevalence, persistency, and detrimental effect on milk production in a drylot dairy. J. Dairy Sci. 1995, 78, 1068-1072. [CrossRef]

11. Silverlas, C.; Naslund, K.; Bjorkman, C.; Mattsson, J.G. Molecular characterisation of Cryptosporidium isolates from Swedish dairy cattle in relation to age, diarrhoea and region. Vet. Parasitol. 2010, 169, 289-295. [CrossRef]

12. Santin, M.; Trout, J.M.; Fayer, R. A longitudinal study of cryptosporidiosis in dairy cattle from birth to 2 years of age. Vet. Parasitol. 2008, 155, 15-23. [CrossRef]

13. Åberg, M.; Emanuelson, U.; Troell, K.; Björkman, C. Infection dynamics of Cryptosporidium bovis and Cryptosporidium ryanae in a Swedish dairy herd. Vet. Parasitol. 2019, 276, 100010. [CrossRef]

14. Murakoshi, F.; Xiao, L.; Matsubara, R.; Sato, R.; Kato, Y.; Sasaki, T.; Fukuda, Y.; Tada, C.; Nakai, Y. Molecular characterization of Cryptosporidium spp. in grazing beef cattle in Japan. Vet. Parasitol. 2012, 187, 123-128. [CrossRef]

15. Ng, J.; Yang, R.; McCarthy, S.; Gordon, C.; Hijjawi, N.; Ryan, U. Molecular characterization of Cryptosporidium and Giardia in pre-weaned calves in Western Australia and New South Wales. Vet. Parasitol. 2011, 176, 145-150. [CrossRef]

16. Ryan, U.; Fayer, R.; Xiao, L. Cryptosporidium species in humans and animals: Current understanding and research needs. Parasitology 2014, 141, 1667-1685. [CrossRef]

17. Feng, Y.; Xiao, L. Molecular epidemiology of cryptosporidiosis in China. Front. Microbiol. 2017, 8, 1701. [CrossRef]

18. Fan, Y.; Huang, X.; Guo, S.; Yang, F.; Yang, X.; Guo, Y.; Feng, Y.; Xiao, L.; Li, N. Subtyping Cryptosporidium xiaoi, a common pathogen in sheep and goats. Pathogens 2021, 10, 800. [CrossRef]

19. Jiang, W.; Roellig, D.M.; Guo, Y.; Li, N.; Feng, Y.; Xiao, L. Development of a subtyping tool for zoonotic pathogen Cryptosporidium canis. J. Clin. Microbiol. 2021, 59, e02474-20. [CrossRef]

20. Rojas-Lopez, L.; Elwin, K.; Chalmers, R.M.; Enemark, H.L.; Beser, J.; Troell, K. Development of a gp60-subtyping method for Cryptosporidium felis. Parasites Vectors 2020, 13, 39. [CrossRef]

21. Cevallos, A.M.; Zhang, X.; Waldor, M.K.; Jaison, S.; Zhou, X.; Tzipori, S.; Neutra, M.R.; Ward, H.D. Molecular cloning and expression of a gene encoding Cryptosporidium parvum glycoproteins gp40 and gp15. Infect. Immun. 2000, 68, 4108-4116. [CrossRef]

22. Yang, X.; Huang, N.; Jiang, W.; Wang, X.; Li, N.; Guo, Y.; Kvac, M.; Feng, Y.; Xiao, L. Subtyping Cryptosporidium ryanae: A common pathogen in bovine animals. Microorganisms 2020,8, 1107. [CrossRef]

23. Xu, Z.; Li, N.; Guo, Y.; Feng, Y.; Xiao, L. Comparative genomic analysis of three intestinal species reveals reductions in secreted pathogenesis determinants in bovine-specific and non-pathogenic Cryptosporidium species. Microb. Genom. 2020, 6, e000379. [CrossRef]

24. Feng, Y.; Gong, X.; Zhu, K.; Li, N.; Yu, Z.; Guo, Y.; Weng, Y.; Kvac, M.; Feng, Y.; Xiao, L. Prevalence and genotypic identification of Cryptosporidium spp., Giardia duodenalis and Enterocytozoon bieneusi in pre-weaned dairy calves in Guangdong, China. Parasites Vectors 2019, 12, 41. [CrossRef]

25. Cai, M.; Guo, Y.; Pan, B.; Li, N.; Wang, X.; Tang, C.; Feng, Y.; Xiao, L. Longitudinal monitoring of Cryptosporidium species in pre-weaned dairy calves on five farms in Shanghai, China. Vet. Parasitol. 2017, 241, 14-19. [CrossRef]

26. Li, P.; Cai, J.; Cai, M.; Wu, W.; Li, C.; Lei, M.; Xu, H.; Feng, L.; Ma, J.; Feng, Y.; et al. Distribution of Cryptosporidium species in Tibetan sheep and yaks in Qinghai, China. Vet. Parasitol. 2016, 215, 58-62. [CrossRef]

27. Ma, J.; Li, P.; Zhao, X.; Xu, H.; Wu, W.; Wang, Y.; Guo, Y.; Wang, L.; Feng, Y.; Xiao, L. Occurrence and molecular characterization of Cryptosporidium spp. and Enterocytozoon bieneusi in dairy cattle, beef cattle and water buffaloes in China. Vet. Parasitol. 2015, 207, 220-227. [CrossRef] 
28. Xiao, L.; Morgan, U.M.; Limor, J.; Escalante, A.; Arrowood, M.; Shulaw, W.; Thompson, R.; Fayer, R.; Lal, A.A. Genetic diversity within Cryptosporidium parvum and related Cryptosporidium species. Appl. Environ. Microbiol. 1999, 65, 3386-3391. [CrossRef] [PubMed]

29. Strong, W.B.; Gut, J.; Nelson, R.G. Cloning and sequence analysis of a highly polymorphic Cryptosporidium parvum gene encoding a 60-kilodalton glycoprotein and characterization of its 15-and 45-kilodalton zoite surface antigen products. Infect. Immun. 2000, 68, 4117-4134. [CrossRef] [PubMed]

30. Li, N.; Xiao, L.; Alderisio, K.; Elwin, K.; Cebelinski, E.; Chalmers, R.; Santin, M.; Fayer, R.; Kvac, M.; Ryan, U.; et al. Subtyping Cryptosporidium ubiquitum, a zoonotic pathogen emerging in humans. Emerg. Infect. Dis. 2014, 20, 217-224. [CrossRef] [PubMed]

31. Guo, Y.; Cebelinski, E.; Matusevich, C.; Alderisio, K.A.; Lebbad, M.; McEvoy, J.; Roellig, D.M.; Yang, C.; Feng, Y.; Xiao, L.; et al. Subtyping novel zoonotic pathogen Cryptosporidium chipmunk genotype I. J. Clin. Microbiol. 2015, 53, 1648-1654. [CrossRef]

32. Stensvold, C.R.; Elwin, K.; Winiecka-Krusnell, J.; Chalmers, R.M.; Xiao, L.; Lebbad, M. Development and application of a gp60-based typing assay for Cryptosporidium viatorum. J. Clin. Microbiol. 2015, 53, 1891-1897. [CrossRef]

33. Yan, W.; Alderisio, K.; Roellig, D.M.; Elwin, K.; Chalmers, R.M.; Yang, F.; Wang, Y.; Feng, Y.; Xiao, L. Subtype analysis of zoonotic pathogen Cryptosporidium skunk genotype. Infect. Genet. Evol. 2017, 55, 20-25. [CrossRef]

34. Feng, Y.; Torres, E.; Li, N.; Wang, L.; Bowman, D.; Xiao, L. Population genetic characterisation of dominant Cryptosporidium parvum subtype IIaA15G2R1. Int. J. Parasitol. 2013, 43, 1141-1147. [CrossRef]

35. Feng, Y.; Tiao, N.; Li, N.; Hlavsa, M.; Xiao, L.; Doern, G.V. Multilocus sequence typing of an emerging Cryptosporidium hominis subtype in the United States. J. Clin. Microbiol. 2013, 52, 524-530. [CrossRef]

36. Feng, Y.; Ryan, U.M.; Xiao, L. Genetic diversity and population structure of Cryptosporidium. Trends Parasitol. 2018, 34, 997-1011. [CrossRef]

37. Qi, M.; Zhang, K.; Huang, M.; Wang, S.; Xu, C.; Wang, T.; Jing, B.; Li, J. Longitudinal detection of Cryptosporidium spp. in 1-10-week-old dairy calves on a farm in Xinjiang, China. Parasitol. Res. 2020, 119, 3839-3844. [CrossRef]

38. Lee, S.-H.; VanBik, D.; Kim, H.-Y.; Lee, Y.-R.; Kim, J.W.; Chae, M.; Oh, S.-I.; Goo, Y.-K.; Kwon, O.-D.; Kwak, D. Multilocus typing of Cryptosporidium spp. in young calves with diarrhea in Korea. Vet. Parasitol. 2016, 229, 81-89. [CrossRef]

39. Silverlås, C.; Bosaeus-Reineck, H.; Näslund, K.; Björkman, C. Is there a need for improved Cryptosporidium diagnostics in Swedish calves? Int. J. Parasitol. 2013, 43, 155-161. [CrossRef] 